\title{
CHARACTERISTICS OF DURIAN SEED BROWNIES WHICH ENRICHED WITH COCONUT FLOUR
}

\author{
Ade Heri Mulyati ${ }^{a *}$, Diana Widiastuti ${ }^{a}$, Ikhwanul Muslimin $^{a}$ \\ ${ }^{a)}$ Universitas Pakuan, Bogor, Indonesia \\ ${ }^{*}$ Corresponding Author: adeheri.mulyati@unpak,ac,id
}

Article history: received 17 December 2018; revised 27 December 2018; accepted 15 January 2019

\begin{abstract}
Abstrak. Durian seed flour is a product selected and used as a fixed variable in future studies. The results of chemical analysis and micro Brownies F2 have a water content of $26.47 \%$, ash $1.63 \%, 16.56 \%$ fat, $6.91 \%$ protein, carbohydrates $48.43 \%$, $\%$ dietary fiber, 4 ALT tests, 3 x 102 cabbage / g, e- coli <3, mold <10 Bacillus Cereus <100. In a subsequent study, Brownies steamed (F8) with a ratio of $75 \%$ wheat flour and seed flour $25 \%$ enriched $20 \%$ Durian pulp has the water content of $26.35 \%$, ash $1.65 \%, 19.58 \%$ fat, $7.20 \%$ protein, carbohydrates $48.53 \%, 12.53 \%$ dietary fiber, 2.7 x 102 ALT test cabbage / g, e-coli <3, mold <10 Bacillus Cereus <100. The shelf life of the conventional product at room temperature $\left(28-30^{\circ} \mathrm{C}\right)$, Brownies control $\mathrm{F} 1$ has the shelf life of 3 days while the Brownies F8 is 6 days, the engine coolant $\left(2-8^{\circ} \mathrm{c}\right)$ Brownies control F1 has the shelf life of 10 days while Brownies F8 14 days.
\end{abstract}

Keywords: durian seed flour; coconut pulp flour; brownies; carbohydrates

\section{INTRODUCTION}

Industry is a human endeavor so that goods obtained from nature can be utilized as products that have a sale value and have a profitable profit in economic terms. Material from nature has chemicals that can be used for certain purposes, such as food, fuel, fuel, fertilizer, cosmetics, etc. so that human life becomes more comfortable. A chemical industry must pay attention to environmental sustainability and is expected to process materials that are safe for the environment, as well as products produced that are environmentally friendly [1]. According to the Central Statistics Agency (BPS) in 2011, Durian (Durio zibethinuss) fruit production in Indonesia was around 1,818,949 tons. Based on the high production and market potential, the amount of durian waste that was not utilized, was very large. During this time the part of durian fruit that was commonly consumed, was the fruit salt or meat (Djaeni, Moh and A, Prasetyaningrum. [2]). The weight percentage of this section is low, which is only $20-35 \%$. This means that $65-80 \%$ of the durian fruit components become waste and are not optimally utilized, the components consist of skin (60-75\%) and seeds $(5-15 \%)$. Durian seeds are part of the durian fruit that is not consumed by most people because of mucus and cause itching on the tongue. Even though it is seen from its nutritional content, durian seeds are quite potent as a source of nutrition, which contains protein, carbohydrates, fats, calcium, and phosphorus. Therefore, durian seeds can be used as an alternative food processing in the form of flour which can add nutrition to the community and create a clean environment (Setio [3]).

Brownies are familiar type of food today. Brownies are one of the famous foods and are favorite of many people. Brownies are generally made by baking. However, there is also much processing by steaming. Brownies have a dense texture, are not hollow, and are not so soft, because they are not as fluffy as most cakes (Ayustaningwarno [4]). Currently, Brownies have been processed with various mixtures. Starting from sweet potatoes, pumpkin, to tempe. But in all these products still use the same main ingredient, namely wheat flour. Wheat flour is flour or powder derived from wheat seeds. The word flour in Indonesian comes from Portuguese, trigo which means wheat. Wheat flour contains a lot of starch, which is complex carbohydrates that are not soluble in water. Based on this, researchers are interested in processing durian seeds into flour and processing them into raw materials for making Brownies.

Coconut pulp is an industrial waste or household waste that is very potential to be used as broiler feed ingredients because coconut pulp is still easily obtained from the rest of the manufacture of traditional coconut oil and waste making Virgin Coconut Oil (VCO) (Yamin [5]). Previously, coconut pulp was only used as animal feed. Whereas with relatively small capital, coconut pulp can be processed into other products such as flour (Kailaku [6]). Along with the development of technology, coconut pulp is not only used as animal feed but as human food (Rosida and Manggaran [7]). Coconut pulp is a good source of protein, gluten free and has a low digestible carbohydrate content. However, the main advantage of coconut pulp is that the food fiber content is very high. The purpose of this study was to determine the quality of durian seed flour Brownies enriched with coconut pulp.

\section{RESEARCH METHODS}

The first stage began with the manufacture of durian seed flour from local varieties (durio zibethinuss $l$ ). Then the characteristic of coconut pulp flour produced was observed. In the second stage, the production of steamed Brownies 
with different formulations of jackfruit seeds, flour, and coconut pulp flour was made and then conducted the organoleptic tests, proximate analysis, and microbiological products which were selected from the organoleptic test results. After that, the shelf life of the Brownies was chosen by using the Extended Storage Studies (ESS) method.

The first stage began with the manufacture of durian seed flour from local varieties (Durio Zibethinuss L). Then the characteristic of coconut pulp flour produced was observed. In the second stage, the production of steamed Brownies with different formulations of jackfruit seeds, flour, and coconut pulp flour was made and then conducted the organoleptic tests, proximate analysis, and microbiological products which were selected from the organoleptic test results. After that, the shelf life of the Brownies was chosen by using the Extended Storage Studies (ESS) method.

\section{Making Coconut Flour}

The stages of the process of making coconut pulp are first weighed $1 \mathrm{~kg}$ of coconut pulp, put it into the boiling pan and then add the water until the coconut pulp is submerged (amount of pulp: the amount of water $=1: 8$ ). The coconut pulp which added to the water was boiled on the stove and left it into 40 minutes. The results of boiled coconut pulp are removed from the pan and then pressed it by using a simple tool to remove as much water as possible before drying. Then it dried in an oven with a temperature of $50{ }^{\circ} \mathrm{C}$. After drying, the coconut pulp was milled with a flour machine and sifted with an 80 mesh sieve.

\section{Making Steamed Brownies}

Steamed brownies are done by dividing the ingredients into 3 doughs, namely: (1) eggs, sugar, vanilla powder, baking soda, emulsifier, and salt; (2) flour and powdered chocolate; and (3) thawed cooking chocolate margarine and dark. The first mixture is whipped evenly until it expands, then add flour and chocolate powder. Shake it until it is distributed. Next process is to melt cooking chocolate margarine and dark, then put it into the first mixture and shake it again. The finished dough is poured into a pan that has been smeared with margarine then steamed it for 45 minutes. In this research, the steamed brownies with 5 different flour formulations are coded $\mathrm{F}$ as the test replication, the formula was flour (TT) and durian seed flour (TBD).

After determining the composition of flour and Durian Flour formulations, Brownies is preferred by the community, then the concentration of coconut pulp flour is produced which produces the best nutritional Brownies. The results of the steamed brownie formulations were then tested by organoleptic to determine the selected formula by the panelists on the parameters of aroma, taste, color, and texture by using an untrained panelist with 20 people. Tests carried out using a hedonic test (preference test) were carried out in two ways, namely the rating test and the ranking test. The data obtained will be tabulated and analyzed by Analysis Of Variance (ANOVA), if the ANOVA test results state that the sample tested is significantly different from the 0.05 confidence, then further testing can be carried out using the Duncan test. The results of the ranking test are tabulated, then transformed into numbers that can be analyzed using the Friedman test.

The next test is the chemical characterization of steamed brownies from cempedak seed flour carried out by chemical analysis through analysis of water, ash, protein, fat, carbohydrate and dietary fiber content. Microbiological characterization tests were carried out for total plate number (ALT), Escherichia Coli, mold, Bacillus Cereus.

\section{RESULTS AND DISCUSSION}

Based on observations of physical, chemical, and microbiological characteristics, durian seed flour and coconut pulp flour meet the requirements of SNI 3751: 2009 [8] wheat flour as a basic ingredient or additional material in food manufacturing. In the initial study, the making of Brownies substituted with durian seed flour was carried out. Wheat flour (TT) and durian seed flour (TBD) with certain comparisons are mixed with other ingredients to make up the product based on formula literature from previous studies.

The organoleptic test results of 20 panelists can be seen in the following table 1.

Table 1. Hedonic Brownies Test Results

\begin{tabular}{|c|c|c|c|c|}
\hline \multirow{2}{*}{ Formulation } & \multicolumn{4}{|c|}{ Parameter } \\
\cline { 2 - 5 } & Color & Smell & Texture & Taste \\
\hline F1 (control) & $5,65^{\mathrm{c}}$ & $5,65^{\mathrm{b}}$ & $5,80^{\mathrm{b}}$ & $5,35^{\mathrm{b}}$ \\
F2 & $6,10^{\mathrm{c}}$ & $5,30^{\mathrm{b}}$ & $5,85^{\mathrm{b}}$ & $5,55^{\mathrm{b}}$ \\
F3 & $4,75^{\mathrm{b}}$ & $5,05^{\mathrm{b}}$ & $3,95^{\mathrm{a}}$ & $3,90^{\mathrm{a}}$ \\
F4 & $4,40^{\mathrm{b}}$ & $4,90^{\mathrm{b}}$ & $3,90^{\mathrm{a}}$ & $3,45^{\mathrm{a}}$ \\
F5 & $3,60^{\mathrm{a}}$ & $4,10^{\mathrm{b}}$ & $3,50^{\mathrm{a}}$ & $3,35^{\mathrm{a}}$ \\
\hline
\end{tabular}

Description: Values followed by different letters show a significantly different treatment for the Duncan test $(\alpha=0.05)$.

Color can determine the quality of the material or product produced. Besides that color can also be used as an indicator of maturity. The average organoleptic results of color attributes in panelists ranged from $3.60 \%-6.10 \%$. The results of the ANOVA statistical test of color parameters indicate that the number of additions of durian seed flour does not have a significant significant effect on Brownies. There is no significant difference between the four Brownies formulas because the color in Brownies is influenced by the use of chocolate block and chocolate powder. The dark cooking chocolate formula and chocolate powder used in the same amount on the four steamed Brownies formulas. The four Brownies have the same color, blackish brown.

The results of organoleptic tests on the aroma parameters of Brownies with the addition of durian seeds ranged from $4.10 \%-5.60 \%$. The results of analysis of variance of aroma parameters showed that the more the amount of durian seed flour added to the Brownies did not have a significant effect on Brownies without the addition of durian seed flour marked by no difference in notation as well as taste parameters indicating that the addition of coconut pulp flour did not have a significant effect (Wirawan [9]). 
The results of the analysis of the fingerprint of the texture parameter rating test showed that formula 1 and formula 2 were significantly different from formulas 3.4 and 5 at a $95 \%$ confidence interval. The average level of panelists' preference for texture attributes ranged from $3.50 \%$ $-5.80 \%$. The statistical test results of ANOVA texture parameters showed that the higher the addition of durian seed flour gave a real difference to the texture of the Brownies produced. The texture of good brownies is moist.

he taste test results show that the formulation has a significant effect on the taste parameter at a $95 \%$ confidence interval. Formula 1, 2 and 3 are not significantly different, while formulas 4 and 5 are significantly different from formulas 1,2 and 3 .

Table 2. Physical Characteristics of Brownies with Comparison Formula of Durian Wheat Flour and Seed Flour.

\begin{tabular}{|c|c|c|c|c|c|}
\hline \multirow{2}{*}{ Parameter } & \multicolumn{5}{|c|}{ Formula } \\
\cline { 2 - 6 } & F1 & F2 & F3 & F4 & F5 \\
\hline Color & $\begin{array}{c}\text { Dark } \\
\text { Chocolate }\end{array}$ & $\begin{array}{c}\text { Dark } \\
\text { Chocolate }\end{array}$ & $\begin{array}{c}\text { Dark } \\
\text { Chocolate }\end{array}$ & $\begin{array}{c}\text { Dark } \\
\text { Chocolate }\end{array}$ & $\begin{array}{c}\text { Dark } \\
\text { Chocolate }\end{array}$ \\
\hline Smell & $\begin{array}{c}\text { Chocolate } \\
\text { Smell }\end{array}$ & $\begin{array}{c}\text { Chocolate } \\
\text { Smell }\end{array}$ & $\begin{array}{c}\text { Chocolate } \\
\text { Smell }\end{array}$ & $\begin{array}{c}\text { Chocolate } \\
\text { Smell }\end{array}$ & $\begin{array}{c}\text { Chocolate } \\
\text { Smell }\end{array}$ \\
\hline Texture & Soft & Soft & Soft & A bit sticky & $\begin{array}{c}\text { Sticky } \\
\text { uneven }\end{array}$ \\
\hline
\end{tabular}

Physical characteristics of control Brownies or F1 ( $100 \%$ flour) and selected formula F2 (25\% durian seed flour) can be seen in the picture below.
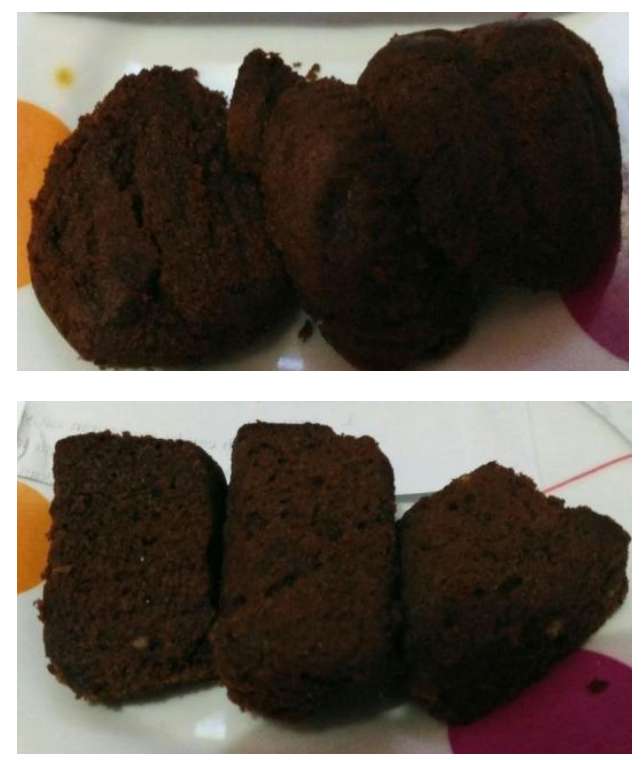

Figure 1. F1 Brownies control (100\%), F2 selected Brownies Wheat Flour 25\% Durian Seed Flour)

Selected steamed brownies are F8 with a ratio of $75 \%$ wheat flour and $25 \%$ durian seed flour which is added by $20 \%$ coconut pulp flour. The chemical characteristics of steamed Brownies can be seen in the following table 3 .

The water content in selected steamed Brownies is $26.35 \%$, the ash content is $1.65 \%$. The substitution of coconut pulp flour on flour and durian seed flour in F8 Brownies showed higher ash content. The fat content in the selected Brownies was $19.58 \%$ because coconut pulp flour used had a higher fat content than wheat flour which was 45 , $37 \%$. Fat is an energy source for the body that can provide an energy value greater than carbohydrate and protein, which is $9 \mathrm{kcal}$ per gram. Protein content is $7.20 \%$ because the coconut pulp flour used has a higher protein content than wheat flour which is $13,26 \%$.

Table 3. Characteristics of Chemical Steamed Brownies of Wheat Flour and Flour of Durian Seeds Enriched with Coconut Powder Flour.

\begin{tabular}{|c|c|c|c|c|}
\hline No. & Parameter & Unit & F6 & F8 \\
\hline 1. & Water & & 26,47 & 26,35 \\
2. & Ash & & 1,63 & 1,65 \\
3. & Protein & $\%$ & 6,91 & 7,20 \\
4. & Fat & & 16,56 & 19,58 \\
5. & Carbohydrate & & 48,43 & 48,53 \\
6. & Food Fiber & & 2,81 & 12,55 \\
\hline
\end{tabular}

Addition of coconut pulp flour to the formula of durian seed flour Brownies can cause an increase in carbohydrate content in durian seed flour Brownies. Food Fiber is determined by the principle of gravimetric enzymatic namely hydrolysis of digestible carbohydrates, fats, proteins using enzymes. Insoluble or soluble hydrolyzed molecules are separated by filtration as residues gravimetrically. F8 Brownies have food fiber levels of $12.55 \%$, while standard Brownies fiber content is $2.81 \%$. The Food Standards Agency recommends that products that claim to be a source of fiber must contain 3 grams of fiber per $100 \mathrm{~g}$. The F8 Brownies product produced has a very high fiber content exceeding the fiber source requirements, so the Brownies product can be used as a source of food fiber in functional food production.

Microbiological analysis is one of the important analyzes because in addition to estimate the shelf life of a food, it can also be used as an indicator of food sanitation or food safety indicators. Microbiological tests carried out on tapioca flour and coconut pulp flour included the ALT test, Escherichia coli, Kapang, and Bacillus cereus.

Control brownies have an ALT content of $4.1 \times 102$ $\mathrm{col} / \mathrm{g}$. Selected brownies have a total plate count (ALT) of $2.7 \times 103 \mathrm{col} / \mathrm{g}$. Both of these ALT results meet the SNI requirements for wheat flour. Escherichia coli content $<3$ APM/g. SNI for wheat flour 3751: 2009 [8] stipulates the requirements of Escherichia coli for wheat flour to a maximum of $10 \mathrm{APM} / \mathrm{g}$, mold content of $<10 \mathrm{cols} / \mathrm{g}$. SNI SNI Wheat flour 3751: 2009 [8] sets mold conditions for max flour. 1 x $104 \mathrm{Kol} / \mathrm{g}$ so that the Brownies still meet SNI requirements. The content of Bacillus cereus is less than 100 Kol / g. SNI Wheat flour 3751: 2009 [8] stipulates that Bacillus cereus requirements for wheat flour must be $<100$ Kol / g so that the two flour meet SNI quality standard requirements.

Determination of shelf life of steamed F8 Brownies and F1 standard Brownies used the conventional Extended Storage Studies (ESS) method. Selected brownies have a 
higher shelf life than control brownies because the water content in the control Brownies is higher than the selected brownies formulation. The high water content can accelerate microbial growth in food products. For the brownies products, a decrease in quality is characterized by the emergence of texture changes such as hardening, the smell begins to rancid and the appearance of white fungus.

\section{CONCLUSION}

In the study of "The Utilization of Durian Seed Flour Enriched with Coconut Flour at Making Brownies", can be concluded that:

Steamed brownies with a ratio of $75 \%$ wheat flour and $25 \%$ Durian seed flour which has a moisture content of $26.47 \%, 1.63 \%$ ash, $16.56 \%$ fat, $6.91 \%$ protein, $48.43 \%$ carbohydrate, fiber food $2.81 \%$, ALT $4.3 \times 102 \mathrm{col} / \mathrm{g}$, e-coli $<3$, mold <10, Bacillus Cereus <100 meet SNI 01-38491995 sweet bread quality standards.

Steamed brownies with a ratio of $75 \%$ flour and $25 \%$ Durian seed flour enriched with $20 \%$ which has a moisture content of $26.35 \%, 1.65 \%$ ash, $19.58 \%$ fat, $7.20 \%$ protein, carbohydrate $48,53 \%$, food fiber $12.53 \%$, ALT test $2.7 \mathrm{x}$ $102 \mathrm{col} / \mathrm{g}$, e-coli $<3$, mold $<10$, Bacillus Cereus $<100$ with shelf life at room temperature $\left(28-30{ }^{\circ} \mathrm{C}\right)$ are 7 days and shelf life at refrigerator temperature $\left(2-8^{\circ} \mathrm{C}\right)$ is 14 days.

\section{Acknowledgement}

This research was conducted with research funding support from the Ministry of Research and Technology based on research on 2018 budget letter number 02 / LPPMUP / KP-PSNI / II / 2018 between research institutions and community service with lecturers / researchers from the University of Pakuan as derivatives of contract research between Kopertis Region IV and Pakuan University number 0801 / K4 / KM / 2018.

\section{REFERENSI}

[1] P. Citroreksoko, A. Taufik, A. Murharini, S. Purawisastra, and Y. Suchyadi. 2012. Kimia Terapan, 1st ed. Jakarta: Universitas Terbuka.

[2] Djaeni, Moh dan A, Prasetyaningrum. 2010. Kelayakan Biji Durian Sebagai Bahan Pangan Alternatif : Aspek Nutrisi dan Teknoekonomi. Riptek, volume 4 No I1 Hal 37-45. Semarang

[3] Setio, RoniWare. 2013. Pengaruh Penambahan Pati Biji Durian (Durio zibethinus Murr) Terhadap Kualitas Fisik Bakso Daging Ayam. Sarjana thesis, Universitas Brawijaya.

[4] Ayustaningwarno, dkk. 2014. Aplikasi Pengolahan Pangan. Yogyakarta. Deepublish.

[5] Yamin, Moh. 2008. Pemanfaatkan Ampas Kelapa Dan Ampas Kelapa Fermentasi Dalam Ransum Terhadap Efesiensi Ransum Dan Income Over Feed Cost Ayam Pedaging. Jurnal Agroland 15 (2) : 135 139.
[6] Kailaku, S. I., 2011. Potensi Tepung Kelapa dari Ampas Industri Pengolahan Kelapa. Laporan Penelitian. Balai Besar Penelitian dan Pengembangan Pasca Panen Pertanian.

[7] Rosida. T. Susilowati, Manggaran. D.A. 2008 Pembuatan Cookies Kelapa (Kajian Proporsi Tepung Terigu: Tepung Ampas Kelapa dan Penambahan Kuning Telur). Jurusan Teknologi Pangan FTI UPN, Jawa Timur

[8] Standar Nasional Indonesia (SNI). 3751-2009. Tepung Terigu Sebagai Bahan Makanan. Jakarta : Badan Standardisasi Nasional

[9] Wirawan, Yudha. 2010. Pengaruh Penambahan Pati Biji Durian Terhadap Kualitas Kimia dan Organoleptik Bakso Ayam. Fakultas Teknologi Pertanian Universitas Brawijaya. Malang. 